\title{
Correction to: Childhood, Science Fiction, and Pedagogy
}

\author{
David W. Kupferman and Andrew Gibbons
}

\section{Correction to:}

D. W. Kupferman and A. Gibbons (eds.),

Childhood, Science Fiction, and Pedagogy, Children:

Global Posthumanist Perspectives and Materialist Theories, https://doi.org/10.1007/978-981-13-6210-1

The book was inadvertently published with errors in the Front matter. The same has been corrected in the book.

The following correction were made in the book Front matter:

The "List of Contributors" was added in the Front matter.

The Front matter have been now updated with the correction. 